\title{
Akulturasi Budaya Hibrid pada Pagelaran Musik Jazz Gunung sebagai Identitas Global dalam Meningkatkan Potensi Wisata
}

\author{
Hybrid Cultural Acculturation in Jazz Mountain Music as a \\ Global Identity to Increase Potential Tourism
}

\author{
Moch. Djauhari \\ Jokhanan Kristiyono \\ Sekolah Tinggi Ilmu Komunikasi - Almamater Wartawan Surabaya \\ (Stikosa-AWS) \\ Alamat: Nginden Intan Timur 1/18, Surabaya \\ djauhari@stikosa-aws.ac.id
}

Dikirim: 4 Mei 2020, Direvisi: 12 Mei 2020, Diterima: 16 Juni 2020, Terbit: 18 Juni 2020

Sitasi: Djauhari, M; Kristiyono, J. (2020). Akulturasi Budaya Hibrid pada Pagelaran Musik Jazz

Gunung sebagai Identitas Global dalam Meningkatkan Potensi Wisata. PRoMEDIA. Volume 6 (1),

Juni 2020, hal 99- hal 122

\begin{abstract}
This study analyzes the process of acculturation of hybrid culture in the performing arts of Mount Bromo Jazz with the local culture of the Tengger tribe. The acculturation of hybrid culture as a global identity in increasing local tourism potential is the culture of the Tengger tribe, Bromo. By using a discourse analysis research methodology, researchers analyze and describe the dialectics to the discourse that occurs in the process of acculturation of hybrid culture at the Bromo mountain jazz. performance. The development of Jazz music spread throughout the world, including in Indonesia. Jazz music is quite popular and is loved by many people, especially young people. At present, there are enough jazz shows that are often held in Indonesia. It is interesting to study and analyze that in this Bromo Jazz music performance the concept of performance and music is a combination of local culture and western culture. Performances by local Indonesian musicians together with global musicians around the world. Some new music works were created through a collaborative process between local musicians and foreign
\end{abstract}


(global) musicians. The results of this study are the local culture of the Tengger tribe with global culture, namely the performance of jazz music into the potential of hybrid culture acculturation in the Sukapura Probolinggo East Java region. This study also illustrates how the process of creating a hybrid culture in Bromo Jazz music performance. The conclusions obtained from this study are the development of the hybrid music culture of Mount Bromo Jass as a potential world-class tourist destination.

Keywords: Hybrid Culture, Bromo Mountain Jazz, Acculturation, Identity

\begin{abstract}
Abstraksi
Penelitian ini menganalisa proses akulturasi budaya hibrid pada seni pertunjukan Jazz Gunung Bromo dengan budaya lokal suku Tengger. Akulturasi budaya hybrid sebagai identitas global dalam meningkatkan potensi wisata lokal yaitu budaya suku Tengger, Bromo. Dengan menggunakan metodologi penelitian analisa wacana, peneliti menganalisa dan mendeskripsikan dialektika hingga diskursus yang terjadi dalam proses akulturasi budaya hybrid pada pagelaran musik jazz gunung Bromo. Perkembangan musik Jazz menjalar ke seluruh dunia, termasuk di Indonesia. Musik jazz tergolong musik yang cukup populer dan disenangi oleh banyak kalangan, terutama anak muda. Menarik dikaji dan dianalisa bahwa pada pagelaran musik Jazz Gunung Bromo ini konsep pertunjukan dan karya musiknya merupakan gabungan antara budaya lokal dan budaya barat. Pertunjukan para musisi lokal Indonesia bersama dengan para musisi global dunia. Beberapa karya musik baru diciptakan dengan proses kolaborasi bersama antara musisi lokal dengan musisi luar (global). Hasil dari penelitian ini adalah Budaya lokal suku Tengger dengan budaya global yaitu seni pertunjukan musik jazz menjadi potensi akulturasi budaya hybrid di kawasan Sukapura Probolinggo Jawa Timur. Penelitian ini juga menggambarkan bagaimana proses terciptanya budaya hybrid pada pagelaran music Jazz Gunung Bromo. Simpulan yang didapat dari penelitian ini adalah
\end{abstract}


pengembangan budaya hybrid musik Jass Gunung Bromo sebagai potensi destinasi wisata berkelas dunia

\section{Kata Kunci: Hibrid, Jazz Gunung Bromo, Akulturasi, Identitas}

\section{PENDAHULUAN}

Musik merupakan salah satu medium komunikasi dan interaksi sosial yang hingga saat ini menjadi media informasi yang sering digunakan. Musik bukan hanya untuk menyampaikan pesan atau informasi tetapi dengan musik manusia dapat menuangkan perasaan, kesan terhadap sesuatu atau seseorang. Perkembangan dunia musik saat ini luar biasa pesat dalam industri musik dunia, mulai dari genre musik yang selalu dinamis hingga platform dan bentuk format musik itu dikemas dalam format digital hingga dapat digunakan atau diperdengarkan dimanapun, kapanpun dan oleh siapapun.

Musik Jazz merupakan salah satu genre musik dunia, yang pada awal kemunculannya diciptakan dan diperkenalkan oleh masyarakat kulit hitam di Negara Amerika sebagai bentuk pemberontakan (rebel) dan protes terhadap masyarakat kulit putih dan pemerintahan negara Amerika pada awal tahun 1920 yang merupakan tahun-tahun masa perbudakan di Amerika. Musik Jazz pada saat masa perbudakan merupakan musik yang hanya bisa diperdengarkan atau dimainkan pada tempat-tempat berkumpulnya para budak kulit hitam. Pada tempat-tempat tersebut beberapa juga merupakan bar atau café yang menjadi 
ruang publik diskusi, pertukaran informasi, perbincangan, bahkan dapat menimbulkan pergerakan demokrasi pada saat itu yang disebut tindakan komunikatif Deliberasi oleh Habermas dikarenakan adanya ruang publik (Lubenow, 2012).

Perkembangan musik Jazz sendiri hingga menjalar ke seluruh dunia, termasuk di Indonesia.Musik Jazz dikenalkan pertama kali oleh pemusik atau musisi dari Negara Filipina pada tahun 1930an yang hingga saat ini terus berkembang. Musik jazz tergolong musik yang cukup populer dan disenangi oleh banyak kalangan, terutama anak muda. Saat ini sudah cukup banyak pertunjukan jazz yang sering diadakan di Indonesia, mudah mendengar lagu-lagu dengan genre jazz diputar atau dimainkan di tempat nongkrong seperti kafe-kafe yang mayoritas merupakan tempat berkumpulnya anak muda.

Komunitas jazz pun berkembang di berbagai kota besar di Indonesia seperti Jakarta, Surabaya, Bandung dan Denpasar. Musik Jazz di Indonesia terus berkembang di kalangan anak muda, tercatat sejak tahun 1978 kegiatan atau festival musik Jazz sudah diselenggerakan oleh Fakultas Ekonomi Universitas Indonesia (FEUI) dengan tajuk Jazz Goes To Campus (JGTC), festival musik Jazz yang diadakan satu tahun setelah dimulainya festival jazz tertua di dunia, North Sea Jazz Festival, dan ini merupakan festival jazz tertua di Indonesia. Festival musik Jazz di Indonesia terus berkembang dan menarik bukan hanya penikmat atau pengunjung festival dari luar negeri tetapi musisi 
Jazz dari manca Negara pun turut serta meramaikan dan tampil di acara-acara festival musik Jazz tersebut.

Pagelaran Jazz Gunung Bromo ini sudah berlangsung 9 (delapan) kali pada tahun 2019 ini dilaksanakan pada bulan Juli tanggal 26 hingga 27 tahun 2019. Pertunjukan musik Jazz di Amphiteater Bromo Jiwa Jawa Resort Bromo, kawasan Sukapura Probolinggo Jawa Timur sudah dilakukan sejak tahun 2012. Menarik dikaji dan dianalisa bahwa pada pagelaran musik Jazz Gunung Bromo ini konsep pertunjukan dan karya musiknya merupakan gabungan antara budaya lokal dan budaya barat. Pertunjukan para musisi lokal Indonesia bersama dengan para musisi global dunia. Beberapa karya musik baru diciptakan dengan proses kolaborasi bersama antara musisi lokal dengan musisi luar (global).

Medium komunikasi informasi berbasis Internet menjadi alat interaksi komunikasi para musisi tersebut dalam proses menciptakan karya bersama dengan platform digital. Kemasan pertunjukan berkelas dunia dengan lokasi yang bernuanasa budaya lokal yang sangat kuat menjadikan pagelaran musik Jazz Gunung Bromo menjadi salah satu agenda pariwisata Indonesia (Kristiyono, 2017b).

Penelitian terdahulu tentang pagelan musik Jazz Gunung dilakukan oleh Dhea Azhar Melati Putri dan Hindun Nurhidayati pada tahun 2018 dengan judul "Faktor Pendorong dan Penarik Wisatawan terhadap Jazz Gunung Bromo sebagai Atraksi Music 
Tourism di Jawa Timur" (Putri \& Nurhidayati, 2018). Dengan tujuan dari penelitian tersebut adalah untuk mengidentifikasi kondisi eksisting Jazz Gunung serta mengidentifikasi faktor pendorong dan penarik wisatawan terkait Jazz Gunung Bromo sebagai atraksi music tourism di Jawa Timur.

Metode penelitian yang digunakan oleh Dhea dan Hindun dalam penelitiannya adalah deskriptif kualitatif, dengan memanfaatkan data primer dan sekunder. Teknik pengumpulan data yang digunakan adalah observasi, wawancara, penyebaran kuesioner, serta dokumentasi. Hasil penelitian terdahulu tersebut menunjukkan bahwa kondisi eksisting Jazz Gunung Bromo sudah memenuhi indikator atraksi dari Walsh-Heron dan Stevens dalam Swarbrooke. Faktor pendorong yang paling dominan dalam mendorong wisatawan untuk menghadiri event Jazz Gunung Bromo adalah motivasi fisik, dan faktor penarik wisatawan yang membuat wisatawan tertarik untuk menghadiri Jazz Gunung Bromo adalah tempat serta pengisi acara.

Perbedaan dengan penelitian terdahulu tersebut adalah penelitian ini melihat proses terjadinya budaya hybrid atau akultasi budaya pada pagelaran music Jazz bertajuk Jazz Gunung yang diselenggarakan di wisata alam Gunung Bromo daerah Sukapura. Daerah yang memiliki budaya dan tradisi yang sangat kuat pada warga lokal yaitu Suku Tengger dengan Budaya Hindu Jawa. Menarik dianalisa dan dikaji bagaimana proses akulturasi 
budaya hibrid yang terjadi antara budaya lokal suku Tengger dengan budaya global pagelaran musik Jazz.

\section{METODOLOGI PENELITIAN}

\section{A. Jenis Penelitian}

Metodologi penelitian ini menggunakan pendekatan studi kualitatif dengan metode Analisa Wacana. Kajian terhadap suatu diskursus atau wacana yang dilakukan secara struktural dengan menghubungkan antara teks dan konteks dalam hal ini proses akulturasi budaya hybrid pada pagelaran musik Jazz Gunung Bromo. Analisa ini juga melihat suatu wacana secara fungsional dengan menganalisis tindakan yang dilakukan seseorang maupun kelompok untuk tujuan tertentu untuk memberikan makna kepada partisipan yang terlibat (Eisenhart \& Johnstone, 2008).

Subyek penelitian yang diteliti adalah proses akulturasi budaya hibrid antara budaya seni pertunjukan musik Jazz yang merupakan budaya global dengan seni budaya suku Tengger sebagai penduduk lokal yang mempunyai budaya yang sangat kuat di Indonesia. Komodifikasi studi budaya dalam dinamika globalisasi sebagai proses pembentukan identitas global untuk meningkatkan potensi wisata di Indonesia.

\section{B. Pengumpulan Data}

Teknik pengambilan data pada penelitian ini menggunakan cara observasi, wawancara mendalam hingga studi pustaka. 
Observasi dilakukan dalam dua tahapan yaitu pertama melakukan observasi mengikuti langsung pagelaran music Jazz Gunung Bromo yang diadakan pada tanggal 26-27 Juli 2019. Pada observasi pertama tersebut peneliti meninjau dan merasakan langsung atmosfir pertunjukan seni musik kelas Internasional atau global pada lokasi desa Sukapura Bromo, tepatnya di area Hotel Jawa Jiwa Resort, Bromo.

Pada observasi tahap kedua dilakukan pada paska pagelaran seni musik tersebut yaitu bulan Nopember 2019. Observasi tahap kedua ini melihat dan berinteraksi langsung dengan masyarakat lokal Suku Tengger, bagaimana proses pola kehidupan dan budaya masyarakat lokal tersebut. Key Informan pada penelitian ini ada 3 orang yaitu Ibu Astika Widya Antengerani selaku Ketua Wanita Hindu Dharma Indonesia Kab. Probolinggo, Bapak Putu Ediantara yang merupakan warga pendatang dari Bali dan sudah menetap lebih dari 12 tahun di Desa Ngadisari Sukapura, dan yang ketiga adalah Bapak Juli selaku Ketua RT Desa Ngadisari yang merupakan warga asli suku Tengger. Ketiga Key Person ini jika dilihat demografi usia rata-rata ketiganya dalam usia 30-40 tahun, Demografi usia yang relatif muda dan literasi komunikasi informasi cukup tinggi, sehingga dapat secara gamblang dan detil dalam memaparkan proses akulturasi budaya di daerahnya. Penelitian ini berlangsung selama 4 bulan (bulan Juli hingga Nopember 2019) dengan proses observasi, wawancara hingga studi pustaka. 


\section{PEMBAHASAN}

\section{A. Akulturasi Budaya Hibrid pada Pagelaran Musik Jazz Gunung}

Manusia sebagai makhluk sosial tidak akan dapat hidup tanpa adanya interaksi sosial, interaksi yang menghubungkan manusia satu dengan lainnya. Interaksi komunikasi dan melakukan kegiatan sosial dengan orang yang memiliki perbedaan budaya merupakan tantangan dan hal baru bagi setiap orang. Manusia selalu berinteraksi dan berkomunikasi dengan orang lain, baik dengan kelompok yang memiliki budaya yang sama atau yang memiliki kebudayaan berbeda. Komunikasi antara dua orang atau lebih baik secara individu maupun kelompok yang memiliki latar belakang kebudayaan berbeda disebut komunikasi antarbudaya (Liliweri, 2017).

Budaya itu memiliki peran penting terhadap globalisasi, begitu sebaliknya globlalisasi itu sangat berarti dan memiliki peran peran penting dalam pertumbuhan budaya (Tomlinson, 2012). Budaya tumbuh dan berkembang tidak lepas dari pertumbuhan globalisasi yang mempengaruhi kondisi lokal atau budaya lokal. Peran globalisasi ekonomi menurut Tomlinson memberikan pengaruh buruk terhadap keberadaan budaya lokal. Tetapi selain dampak buruk dalam globalisasi ekonomi, globalisasi juga dapat memberikan hal baru bahkan dapat menciptakan budaya baru dan jika dapat dikembangkan dan 
dikelola dengan baik maka ekonomi lokal dapat bertumbuh dan berkembang hingga meningkatkan potensi lokal.

Pertumbuhan atau munculnya budaya baru akibat adanya globalisasi terbagi menjadi dua, yaitu akulturasi dan aksimilasi budaya. Pada studi Jazz Gunung Bromo ini terjadi budaya hybrid atau Cultural Hybridity (Burke, 2012), terbentuknya akulturasi budaya dunia yaitu music Jazz bercampur dengan budaya lokal Indonesia dikemas dan dilakukan pagelaran musik di tempat yang mempunyai budaya, kepercayaan, dan tradisi lokal yang sangat kuat yaitu kawasan masyarakat Tengger, Probolinggo Jawa Timur. Pertemuan budaya luar (global) dari musisi luar dengan musisi lokal, melakukan kolaborasi musical Jazz hingga menciptakan aransemen musik Jazz yang baru kental dengan nuansa lokal Indonesia yang dibawa oleh musisi Indonesia. (Kraidy, 2009).

Budaya merupakan gaya hidup yang unik dari suatu kelompok manusia tertentu baik pada daerah yang sama ataupun pada daerah yang berbeda. Budaya adalah bagaimana kelompok manusia menjalani hidup yang berbeda dengan kelompok lainnya manusia lainnya. Dalam hal ini budaya masyarakat Suku Tengger di Sukapura Bromo memiliki tradisi dan budaya yang sangat kental, dengan berbasis ideologi agama Hindu dan tradisi kejawen atau pola hidup Jawa. Pada 8 tahun terakhir bertumbuh kembang budaya baru di lokasi tersebut yaitu pagelan musik dunia Jazz. Pagelaran musik yang dikonsep dan diadakan untuk 
masyarakat modern pada era globlasasi ini. Proses akulturasi budaya hibrid terjadi pada masyarakat daerah tersebut dalam pementasan musik Jazz Gunung Bromo. Wacana atau diskursus yang terjadi dalam proses dialektika dan pertukaran budaya secara fungsional pada budaya suku Tengger dengan adanya pagelaran musik Jazz Gunung. Terjadi proses interaksi komunikasi dan tindakan yang dilakukan seseorang maupun kelompok baik kelompok masyarakat Tengger dengan kelompok masyarakat global dari kota besar di luar Bromo. Masing-masing kelompok masyarakat tersebut memiliki tujuan tertentu untuk memberikan makna kepada partisipan yang terlibat pada pagelaran musik Jazz Gunung Bromo.

\section{B. Budaya Hybrid sebagai Identitas Global dalam}

\section{Meningkatkan Potensi Wisata}

Budaya hibrid saat ini menjadi istilah-istilah yang banyak diperbincangkan dalam ranah kajian sosio-humaniora seperti sosiologi, antropologi, religi, sastra, dan media, meskipun pada awalnya banyak digunakan dalam wacana saintifik. Tidak bisa disangkal lagi, populerisasi istilah-istilah tersebut terkait erat dengan perkembangan wacana poskolonial dan globalisasi yang dari hari ke hari semakin berkembang dalam perdebatan akademis, baik dalam jurnal, buku, maupun mimbar seminar dan konferensi (Kristiyono, 2017a). 
Dalam konteks kedua wacana tersebut, hibridisasi merujuk pada sebuah proses yang mempertemukan dua atau lebih budaya dalam satu ruang kultural yang kemudian menghasilkan strategistrategi untuk melakukan percampuran, namun dengan tujuantujuan politis untuk menegosiasikan kepentingan lokalitas dalam menghadapi "yang dari luar", sebagai akibat dari kolonialisasi dan globalisasi yang memang selalu menghadirkan praktik dan bentuk kultural dari luar ruang lokal (Hatley, 2014).

Dalam perkembangannya, istilah budaya hibrid seringkali hanya dipahami semata-mata sebagai bentuk dan praktik percampuran dua atau lebih budaya dengan hasil sebuah format baru yang berwarna campuraduk tanpa menghilangkan karakteristik budaya-budaya sebelumnya. Terma-terma yang biasa muncul dari konteks tersebut antara lain musik hibrid, film hibrid, ritual hibrid, pakaian hibrid, gaya hidup hibrid, dan masih banyak lagi. Pemahaman tersebut tentu sah-sah saja dalam konteks akademis. Namun demikian, pemahaman tersebut cenderung meletakkan kajian semata-mata pada hasil atau produk percampuran dari hibridisasi untuk kemudian mengkebiri "potensi politis dan strategis" di balik hibridisasi kultural yang berlangsung.

Perkembangan teknologi dan komunikasi saat ini semakin pesat, dengan adanya penemuan-penemuan produk teknologi baru sangat memanjakan masyakat modern yang selalu tidak terpisahkan dengan teknologi tersebut (Kristiyono, 2015). 
Aplikasi komunikasi berbasis Internet terus muncul yang terbaru, dan aplikasi lama terus berlomba-lomba memberikan fitur-fitur baru untuk dapat memberikan layanan terbaik, tercepat dan terkini untuk penggunanya. Kelompok-kelompok sosial terus terbentuk dalam medium sosial media di dunia Internet, kelompok sosial tersebut berkembang dalam hal jumlah dan interaksi sosial komunikasinya hingga terbentuk masyarakat Internet atau biasa disebut Internet Society (Castells, 2003).

Masyarakat atau kelompok pecinta Jazz Gunung Bromo ini juga berkembang dan didukung penuh dengan adanya sosial media dan media Internet lainnya, tercatat Jazz Gunung Bromo mempunyai 4 (empat) akun resmi sosial media mulai dari Facebook, Twitter, Instagram dan YouTube. Selain itu Jazz Gunung Bromo ini juga didukung dari unsur pemerintahan hingga media, medium digital Internet menciptaakan masyarakat yang selalu terkoneksi dengan dunia digital. Format video dan audio pada pementasan atau pagelaran music Jazz Gunung Bromo juga dapat diakses dalam format digital yang dapat dilihat langsung oleh penduduk digital atau Digital Citizen (Booth, 2010).

Seni pertunjukan seperti Jazz Gunung Bromo ini merupakan budaya luar yang muncul pada era globalisasi di masyarakat lokal suku Tengger Bromo. Masyarakat yang memiliki kekuatan tradisi dan budaya yang sangat kuat seperti budaya agama Hindu Kejawen hingga prosesi-prosesi ritual sebagai bentuk identitas 
lokal seperti upacara Kasada dan ritual sesajian kepada leluhur di lokasi-lokasi alam. Ini menunjukkan bahwa identitas lokal dapat berubah menjadi identitas global dengan adanya akulturasi budaya hybrid pada pementasan Jazz Gunung Bromo. Identitas yang menggabungkan antara tradisi, budaya, alam dan kesenian (Burke, 2012). Identitas global ini yang menjadi identitas baru dan mendunia (global) bagi kawasan Bromo yang dulunya terkenal dengan tradisi dan ritual masyarakat Tengger sekarang muncul sebuah identitas baru yaitu Pagelaran Musik Jazz Gunung Bromo. Potensi wisata dunia dari Indonesia (Moch. Djauhari \& Aulia Afniar, 2018).

\section{Analisa}

Berdasarkan hasil observasi pada kawasan desa Ngadisari, Sukapura Bromo yang mengekplorasi dan mengobservasi masyarakat lokal (23/11/2019) di Shelter Wisata Gunung Bromo. Terjadi dialektika dan diskursus antara penyelenggara pagelaran seni musik Jazz Gunung Bromo. Pagelaran ini juga menunjukkan identitas Lokal melalui tradisi, budaya, alam dan kesenian musik. Menurut Bapak Sukik (warga asli suku tengger), tidak ada keterlibatan secara tradisi dan budaya antara suku tengger dengan acara pementasan Jazz Gunung Bromo.

Hanya Ada peningkatan secara ekonomi dikarenakan adanya penonton dari luar dan artis-artis pementas yang tertarik untuk sekaligus melihat dan melakukan wisata Alam. Penyelenggara 
Jazz Gunung itu adalah pemilik Hotel Jiwa Jawa Bromo, semua kepanitian dari masyarakat luar suku Tengger. Kebanyakan dari masyarakat kota besar seperti Surabaya dan Jakarta yang juga aktif dalam komunitas Jazz. Penduduk suku tengger di desa Cemara Lawang sekitar 500 orang, suku tengger di daerah ngadisari mulai sukopuro hingga cemoro lawang sekitar 1000 orang tersebar di berbagai pelosok desa.

Dianalisa menurut tradisi lokal Suku Tengger, hasil wawancara dengan Bapak Putu Ediantara warga pendatang Bali yang sudah lebih dari 12 tahun tinggal dan menikah dengan warga lokal suku Tengger menjelaskan mengenai tradisi Sesajen, yang dilakukan warga di punden-punden sekitar desa. Sesaji ini dilakukan untuk Roro Anteng dan Joko Seger. Ini merupakan kisah legenda gunung Bromo. Pada sekitar lokasi pegunungan Semeru dan Bromo terdapat user-user yauty rumah leluhur 25 anak dari Roro Anteng dan Joko Seger tersebut. Di Ngadisari terdapat 7 lokasi (user-user), yang lainnya tersebar di sekitar kawasan Tengger (Lumajang, Probolinggo, Malang, Pasuruan). Ritual-ritual sesaji ini juga muncul pada setting tempat pagelaran seni music Jazz Gunung Bromo tersebut, mulai dari tempattempat sajian dan obor-obor yang ditampilkan selama pagelaran musik.

Etnik dan ritual sangat tampak kental pada pagelaran musik ini. Pagelaran Jazz Gunung merupakan sebuah pergelaran musik yang berbeda dengan pergelaran musik pada umumnya. Di event 
ini, penonton merasakan perpaduan antara komposisi jazz bernuansa etnik, dengan pemandangan alam pegunungan yang indah dan asri. Sebuah identitas lokal yang dalam bentuk kesenian modern (musik Jazz) dipadu dengan alam gunung Bromo yang memiliki tradisi dan budaya yang kuat.

Menurut Bapak Juli (Ketua RT Desa Ngadisari, Sukapura) menjelaskan bahwa tradisi sesajen di masyarakat Suku Tengger itu merupakan tradisi dan ritual Hindu Jawa. Ritual yang dilakukan pada hari-hari khusus seperti Jumat Legi. Maka masyarakat suku Tengger akan melakukan tetamping untuk proses sesajen. Hari-hari Hindu Jawa seperi Pujan Kelima, Pujan Keenam, Pujan Kepitu (Hari Raya Nyepi), Pujan Kedelapan, Pujan Sanga (melakukan ritual obor), Hari Raya Kasada (prosesi Mayu Desa), hingga Hari Raya Karo. Hari Raya Karo merupakan tradisi asli masyarakat tengger. Masyarakat Tengger melakukan silahkrama silahturami dengan sanak keluarga. Budaya ini namanya Hari Raya Karo. Pada 5 tahun sekali, ada Hari Raya Besar Unan-Unan (Mayu Desa). Pujan Kesanga merupakan ritual perlindungan diri kepada Sang Hyang Widhi. Pujang Kesanga ritual desa untuk membuang balak. Prosesi menggunakan obor dan perapian. 
PROMEDIA (PUBLIC RELATION DAN MEDIA KOMUNIKASI) ISSN 2460-9633

Volume Ke-6 No. 1, 2020, Djauhari, dkk, Akulturasi Budaya, hal 99 - hal 122

Gambar 1. Ritual Obor pada Pujan Kesanga

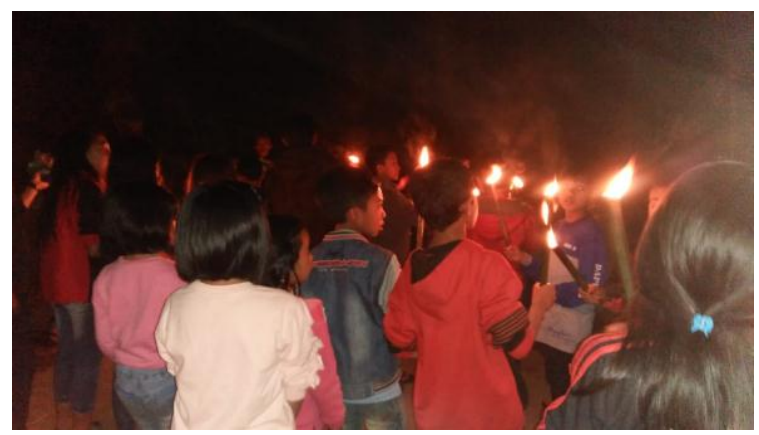

(sumber:https://www.goodnewsfromindonesia.id/2019/10/23/puja n-kesanga-sebagai-perlindungan-diri-kepada-sang-hyang-widhi)

Gambar 2. Pagelaran musik Jazz Gunung 2011 di Kawasan

Wisata Gunung Bromo

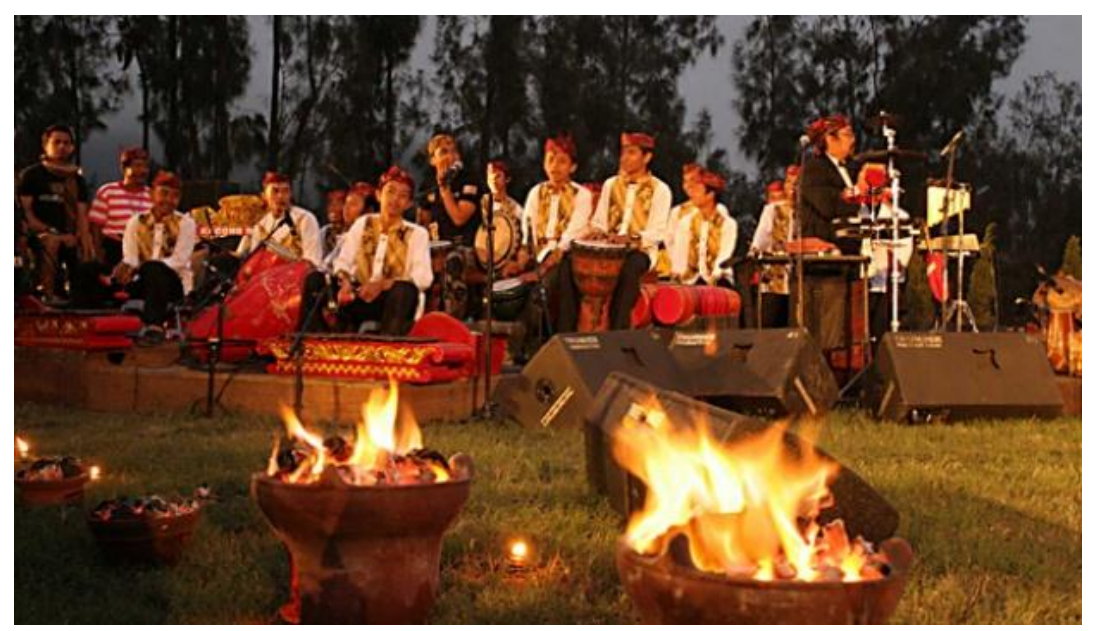

(sumber: tempo.co) 
Pada tahun 2019 ini terdapat perubahan yang sangat mencolok pada proses akulturasi budaya. Tradisi obor sudah dimodernisasi dengan adanya setting lampu-lampu sorot dengan berbagai warna. Pada pagelaran tahun 2019 ini desain eksterior didesain lebih modern dan kelas dunia, ini menunjukkan identitas global pada pagelaran seni music Jazz Gunung Bromo kali ini.

Gambar 3. Setting tempat pagelaran musik Jazz Bromo 2019

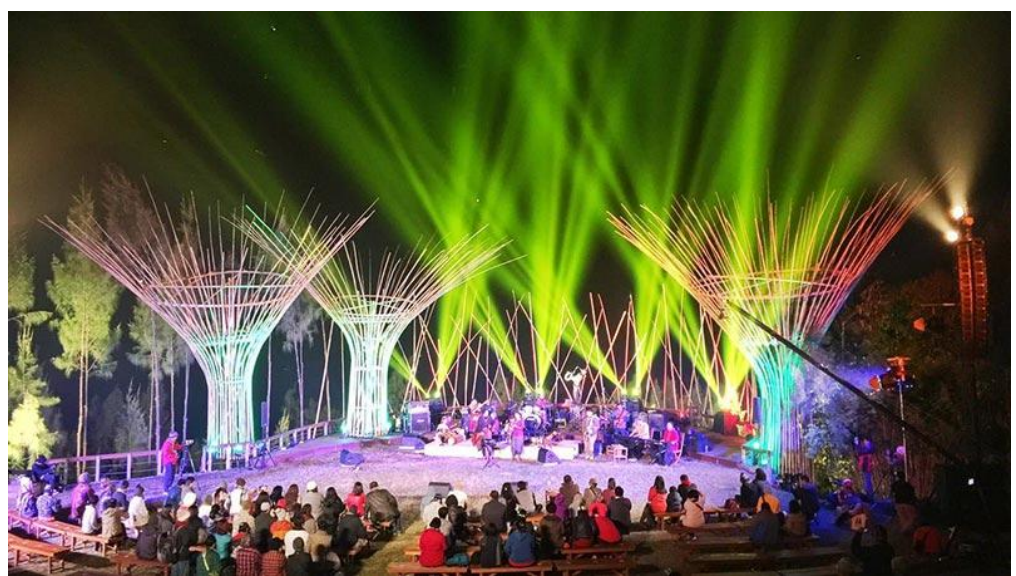

(sumber: https://blogkulo.com/jazz-gunung-bromo-2019/)

Proses akulturasi budaya Hibrid antara budaya lokal masyarakat Tengger dengan budaya pop pagelaran musik Jazz Gunung Bromo, alam Gunung Bromo sebagai lokasi pentas musik dan kesenian music Jazz sebagai media komunikasi. Semuanya dibungkus dalam pagelaran musik kelas dunia (global) yang bertajuk Musik Jazz Gunung Bromo. 
Dialektika kritis juga muncul selama proses wawancara dan observasi pada penelitian ini, wawancara dengan Ibu Astika Widya Antengerani (Ketua WHDI - Wanita Hindu Dharma Indonesia kab. Probrolinggo). Biasa dipanggil ibu Reni, merupakan warga asli suku tengger beragama Hindu yang rutin aktif dan mengikuti kegiatan ritual keagamaan suku Tengger Bromo. Ibu ini merupakan Ketua Perkumpulan atau Komunitas Wanita Hindu Dharma Indonesia untuk Kabupaten Probolinggo.

Komunitas ini merupakan perkumpulan khusus wanita Hindu suku Tengger, yang sangat aktif melakukan kegiatan keagamaan dan ritual budaya. Key informan ini merupakan warga lokal kelahiran tahun 90'an, sangat modernism tetapi sangat aktif dan menghormati tradisi dan budaya suku tengger. Menurut beliau, akulturasi budaya dan tradisi yang terjadi dengan budaya luar pada pagelaran musik Jazz Bromo itu hanya pada setting lokasi dan situasi pementasan seni musik jazz gunung. Pagelaran musik yang dilakukan di resort hotel Jiwa Jawa Bromo. Setting api dan lingkaran pada pementasan dibuat seakan-akan seperti peristiwa ritual musik dan tarian suku Tengger saat tradisi Kasada hingga Larung (sesajen) di kawah gunung bromo. Musik jazz yg ditampilkan di pagelaran jazz gunung murni musik jazz modern dari para artis musisi jazz global, pencampuran budayanya terjadi pada saat proses setting tempat dan situasi kondisi panggung termasuk area penonton. 
Tradisi lokal seni pertunjukan asli dari masyarakat Tengger juga mengalami proses perubahan dan akulturasi dengan budaya tari lainnya. Seni pertunjukan tarian tentang Alam yang bernama Tarian Nawa Dewata. Tarian Nawa Dewata senagai pembuka Kasada di Bromo. Penampilan pertama kali Tarian Nawa Dewata dalam pembukaan resepsi Yadna Kasada 2016 di pendopo agung Desa Ngadisari. Tarian ini merupakan tarian ciptaan baru dari masyarakat Tengger Bromo.

Pada pertunjukan musik Jazz Bromo tahun 2019 ini menampilkan berbagai seniman musik Jazz seniman Indonesia dan luar negeri mulai tanggal 26 hingga 27 Juli 2019, total ada 13 lineup performance. Situasi dan kondisi cukup menarik tampak pada hari terakhir tanggal 27 Juli 2019 pada saat Didi Kempot tampil dengan diiringi musik jazz etnis jawa dari kelompok musik pimpinan Djaduk Ferianto. Selama 2 hari berturut-turut (26-27 Juli) pada saat lineup performance tampil, tidak ada warga setempat khususnya masyarakat suku Tengger ikut terlibat baik sebagai panitia maupun penonton. Tetapi ketika Didi Kempot dengan iringan musik Jazz etnis dari alm. Djaduk Ferianto tampil, cukup banyak masyarakat lokal ingin terlibat sebagai penonton. Ini dikarenakan lagu-lagu dari Didi Kempot yang sangat populer di kalangan masyarakat etnis Jawa (menggunakan dialek dan syair bahasa Jawa), dan dengan iringan musik etnis Jawa membawa kedekatan tersendiri dengan masyarakat lokal. 
Meskipun hanya sebatas sebagai penonton, tidak terjadi keterlibatan aktif proses akulturasi budaya. Harmonisasi masyarakat adat suku Tengger yang berbasis ideologi Hindu Jawa mempunyai modal sosial yang sangat kuat, ikut merasakan dan tertarik penampilan Didi Kempot dan alm. Djaduk Ferianto dengan lagu-lagu bahasa Jawa dengan alunan musik etnis Jawa (Nurcahyono \& Astutik, 2018).

\section{KESIMPULAN DAN SARAN}

Jazz Gunung Bromo adalah pergelaran musik bertaraf internasional yang menampilkan komposisi jazz bernuansa etnik, digelar setiap tahun di daerah pegunungan. Jazz Gunung Bromo merupakan salah satu pionir berkembangnya festival musik yang dilaksanakan di alam terbuka di Indonesia. Para musisi baik nasional maupun internasional, tampil di amfiteater yang beratap langit dan berlatar belakang alam yang indah. Perpaduan harmonis antara musik, alam pegunungan, dan manusia menciptakan indahnya jazz dan merdunya gunung. Akulturasi atau pertukaran budaya hybrid pada pagelaran musik jazz gunung Bromo hanya terjadi sebatas di permukaan atau tidak dalam. Identitas lokal yang ditunjukkan pada akulturasi budaya tersebut hanya muncul di setting lokasi alam yaitu Gunung Bromo dan kesenian musik jazz etnis jawa yang dibawakan oleh Didi Kempot dan alm. Djaduk Ferianto. Itupun bahasa Jawa dan 
alunan music etnis jawa secara umum, bukan hasil akulturasi budaya dari masyarakat lokal.

Terdapat batasan dan perbedaan visi antara penyelenggara Jazz Gunung Bromo dengan masyarakat lokal suku Tengger. Penyelenggara secara profesional berorientasi ekonomi dan nominal dalam proses pagelaran musik kelas dunia ini, sedangkan masyarakat suku Tengger merupakan masyarakat kulturis yang sangat kuat dalam menjaga tradisi dan budayanya. Simpulan yang didapat dalam penelitian ini adalah belum cairnya interaksi komunikasi antar kelompok masyarakat sosial. Belum terjadi dialektika yang harmonis antara kedua kelompok masyarakat sehingga dapat menciptakan budaya hybrid yang lebih kuat sebagai identitas global dalam peningkatan potensi wisata yang mendunia (Jensen, Arnett, \& McKenzie, 2011). 


\section{DAFTAR PUSTAKA}

Booth, P. 2010. Digital Fandom : New Media Studies. Peter Lang - Digital Formations.

Burke, P. 2012. Cultural hybridity. Sociological Research Online. https://doi.org/10.1002/9781405198431.wbeal0297

Castells, M. 2003. The internet galaxy: Reflections on the internet, business and society. Research Policy. https://doi.org/10.1016/S0048-7333(02)00012-4

Eisenhart, C., \& Johnstone, B. 2008. Discourse analysis and rhetorical studies. Rhetoric in Detail: Discourse Analysis of Rhetorical Talk and Text. Amsterdam and Philadelphia: John Benjamins Publishing, 3-21.

Hatley, B. 2014. Pertunjukan Budaya Indonesia Pasca Orde Baru. Seni Pertunjukan Indonesia Pasca Orde Baru, 3.

Jensen, L. A., Arnett, J. J., \& McKenzie, J. 2011. Globalization and cultural identity. In Handbook of identity theory and research (pp. 285-301). Springer.

Kraidy, M. M. 2009. Hybridity, or the cultural logic of globalization. Mass Communication Research, (100), 307314. https://doi.org/10.1177/1742766506069583

Kristiyono, J., \& Sirikit, H. 2019. Menelisik Siasat Cerita Digital Reality pada Film Ready Player One?. Bricolage: Jurnal Magister Ilmu Komunikasi, 5(02), 159-176.

Kristiyono, J. 2017. Budaya Internet: Perkembangan Teknologi Informasi dan Komunikasi dalam Mendukung Penggunaan Media di Masyarakat. Scriptura. https://doi.org/10.9744/scriptura.5.1.23-30

Kristiyono, J. 2017. Film Sebagai Medium Komunikasi Pariwisata. Tourism, Hospitality and Culinary Journal, 2(1), 44-52.

Liliweri, A. 2017. Komunikasi Antar Personal. Prenada Media.

Lubenow, J. A. 2012. Public Sphere and Deliberative Democracy in Jürgen Habermas: Theorethical Model and Critical Discourses. American Journal of Sociological Research, 2(4), 58-71.

https://doi.org/10.5923/j.sociology.20120204.02

Moch. Djauhari, \& Aulia Afniar. 2018. Medium Komunikasi 
Pariwisata Melalui Film Animasi. Jurnal Spektrum Komunikasi. https://doi.org/10.37826/spektrum.v6i2.33

Nurcahyono, O. H., \& Astutik, D. 2018. Harmonisasi Masyarakat Adat Suku Tengger (Analisis Keberadaan Modal Sosial Pada Proses Harmonisasi Pada Masayarakat Adat Suku Tengger, Desa Tosari, Pasuruan, Jawa Timur). Dialektika Masyarakat: Jurnal Sosiologi, 2(1), 1-12.

Putri, D. A. M., \& Nurhidayati, H. 2018. Faktor Pendorong dan Penarik Wisatawan terhadap Jazz Gunung Bromo sebagai Atraksi Music Tourism di Jawa Timur. Journal of Tourism Destination and Attraction, 6(1), 26-38.

Rabbani, K., \& Trijayanto, D. 2019. Ekonomi Politik Media Dalam New Media (Studi Deskriptif Praktik Spasialisasi pada Channel Youtube Atta Halilintar). PROMEDIA (PUBLIC RELATION DAN MEDIA KOMUNIKASI), 5(1).

Tomlinson, J. 2012. Cultural globalization. The Wiley- Blackwell Encyclopedia of Globalization. 